\title{
23. SYNTHESIS OF THE BARBADOS DÉCOLLEMENT SEISMIC REFLECTION RESPONSE FROM DRILLING-BASED GEOPHYSICAL OBSERVATIONS AND PHYSICAL PROPERTIES ${ }^{1}$
}

\author{
Thomas H. Shipley, ${ }^{2}$ Gregory F. Moore, ${ }^{3}$ Harold J. Tobin, ${ }^{4}$ and J. Casey Moore ${ }^{5}$
}

\begin{abstract}
A three-dimensional seismic reflection experiment has revealed a distinctive distribution of waveforms and amplitudes associated with the décollement reflection in the Barbados Trench. One objective of Ocean Drilling Program Leg 156 was to calibrate this seismic reflection response, which was thought to be related to variations in fault zone properties. Site 948 is characterized by a normal polarity reflection that is correlated to the décollement. Sampling and logging reveal a 40-m-thick fault zone, with density that increases across the zone as the clay mineralogy changes from smectite rich to illite rich downhole. A synthetic seismogram, derived from the logging data, shows that the lithology-driven density shift is responsible for generating the normal polarity reflection even though the log, packer, and long-term pressure measurements confirm the presence of abnormally high pressures. The objective of Site 947, to characterize the more common, high-amplitude negative polarity waveform, was not completed due to technical difficulties. However, a density $\log$, run at the beginning of the cruise, did reveal a 14-m-thick $1.6 \mathrm{~g} / \mathrm{cm}^{3}$ layer $540-554 \mathrm{~m}$ below seafloor (mbsf). The bit reached within $60 \mathrm{~m}$ of the décollement, and the density log went to $565.5 \mathrm{mbsf}$. The low-density layer correlates with a fault splay off the décollement, having similar seismic characteristics to that of the negative polarity décollement and can serve as an analogue. Although it is unsatisfying not to have directly calibrated the décollement at Site 947, the fault splay revealed characteristics that are consistent with modeling done before the cruise that required a 12- to 14-m-thick low impedance layer to account for the observed waveform. These very low densities are probably created by introduction of additional fluids and fluidized sediments during hydrofracturing, which are maintained by lithostatic pressure. The requirement for extremely low density indicates that a $>12-\mathrm{m}$-thick lithostatic pressured hydrofractured zone occurs within the thicker décollement. The variations in the amplitude of the negative polarity waveform relate mainly to the amount of enhanced fluid content. The mapped pattern of amplitudes suggests a broad northeast-trending channel that possibly focused fluid transport along the décollement. However, numerous fault splays intersect the décollement, which may cause barriers that prevent rapid fluid flow along the décollement.
\end{abstract}

\section{INTRODUCTION}

In the last decade, observations of fluid seeps in subduction zones, associated with heat and mineral transfer during pore-water advection and fluid-rock chemical exchange, place renewed emphasis on the importance of fluids in accretionary prisms (Kulm et al., 1986; Carson et al., 1990; Kastner et al., 1991; Moore and Vrolijk, 1992). The effects of fluids on fault strength are particularly important in convergent margin toe-of-slope regions where forced tectonic dewatering produce exceptional rates of porosity reduction and fluid expulsion. There is mounting evidence from accretionary prisms at convergent margins that fluids reach pressures far higher than hydrostatic, causing localized weakening, faulting, and even hydrofracturing (J.C. Moore et al., 1995b; Fisher et al., 1996). Multiple cross-cutting sets of veins in accretionary prism rocks indicate crack generation and mineralization induced by cyclic lithostatic fluid pressures and fluid flux (Sibson, 1981). Seismic reflection profiles often provide a coherent mappable reflection associated with the décollement as imaged beneath the Costa Rica, Nankai and Barbados accretionary prisms, and on fault ramps off Oregon that are closely associated with the décollement (e.g., Shipley and Moore, 1986; Shipley et al., 1990 Bangs

${ }^{1}$ Shipley, T.H., Ogawa, Y., Blum, P., and Bahr, J.M. (Eds.), 1997. Proc. ODP, Sci. Results, 156: College Station, TX (Ocean Drilling Program).

${ }^{2}$ Institute for Geophysics, University of Texas, Austin, TX 78759-8397, U.S.A. tom@utig.ig.utexas.edu

${ }^{3}$ Department of Geology and Geophysics, University of Hawaii, Honolulu, HI 96822-2285, U.S.A.

${ }^{4}$ Department of Geophysics, Stanford University, Stanford, CA $94305-2215$, U.S.A. U.S.A.

${ }_{5}^{5}$ Earth Sciences, University of California, Santa Cruz, Santa Cruz, CA 95064-0001, and Westbrook, 1991; Moore et al., 1990; Moore and Shipley, 1993; Tobin et al., 1993; J.C. Moore et al., 1995a). These studies conclude that the presence of unusual volumes of fluids are in a large part responsible for the seismic response of fault zones. In the Nankai and Barbados cases, the seismic waveforms indicate the presence of low density associated with the décollement, and in both areas, recognized changes in the waveform along individual seismic lines are caused by spatial variations in thickness and porosity within the décollement. In this paper we explore the specific seismic response of the décollement off Barbados. Here there is both exceptional wellcontrol and three-dimensional (3-D) seismic data.

The Barbados Trench is the eastward extent of subduction of the North America Plate beneath the Caribbean. The primary locus of shear is revealed in particular detail by the reflectivity and continuity of the fault-plane seismic reflection, enhanced by a setting where other nearby reflecting horizons are often absent or of low amplitude, thus minimizing interference (Westbrook and Smith, 1983). This relatively simple setting and seismic response of the décollement led to a 3-D seismic reflection study that yielded a map view of fault-plane reflection peak amplitude. This map spurred speculation concerning porosity, fluid pressure, fluid flow, and even strength and stress associated with the plate-boundary thrust (Figs. 1, 2; Shipley et al., 1994; G. F. Moore et al., 1995; Bangs et al., 1996). The results of the 3-D survey demonstrate that the seismic response of the décollement varies at mappable scales, leading to the question of just what aspects of the fault properties produce the seismic signal. Ocean Drilling Program (ODP) Leg 156 (June-July 1994) provided an opportunity to calibrate the seismic waveform to the geology of the décollement

Even the small area of the décollement illuminated by the 3-D seismic survey (about $100 \mathrm{~km}^{2}$ of the $125-\mathrm{km}^{2}$ survey area) reveals a scale of heterogeneity that requires calibration to a finite number of drill holes and in situ measurements (Fig. 1). Understanding how the 


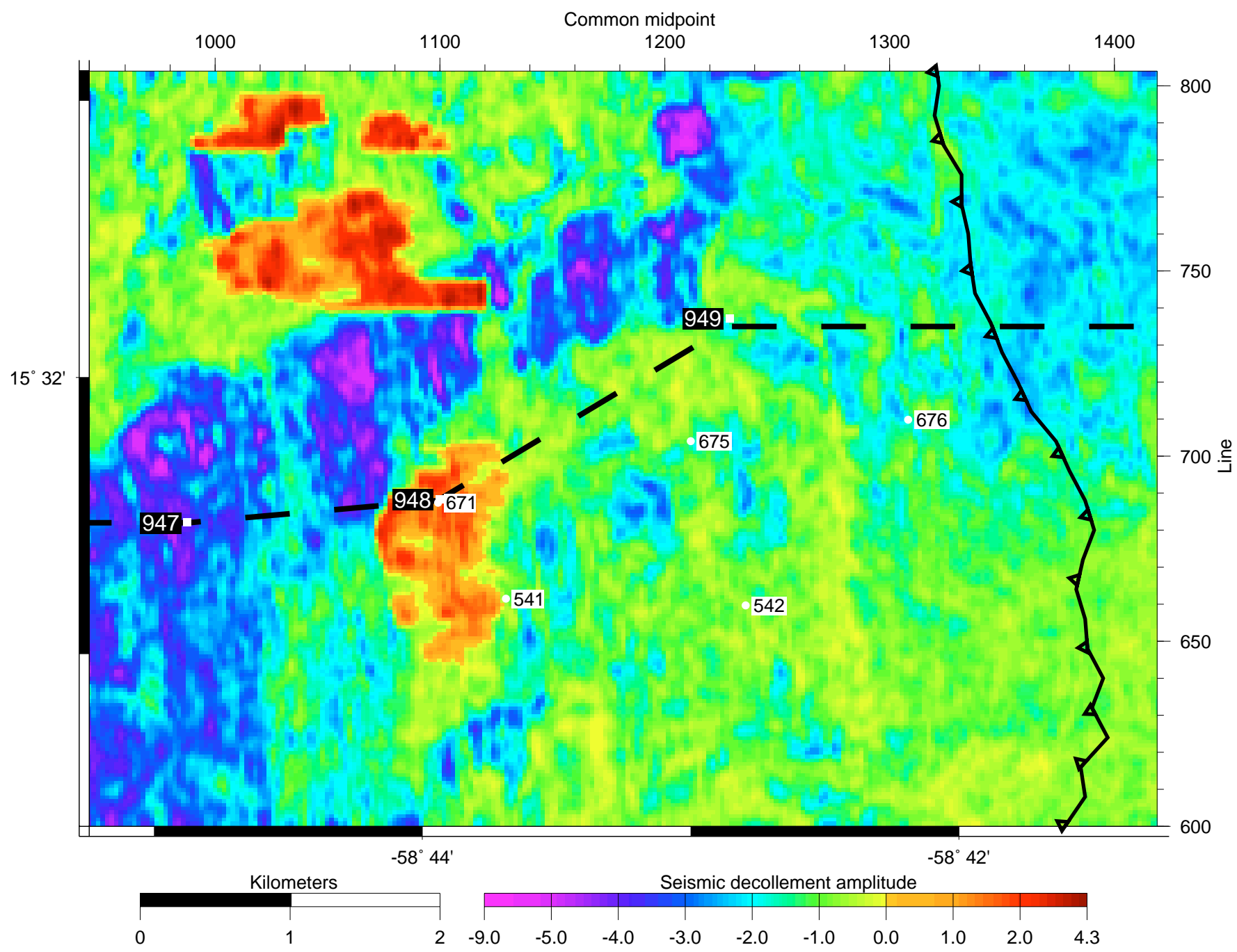

Figure 1. Map showing peak amplitude of the seismic expression of the décollement. Site 948 is located in one of the rare areas of positive polarity (orange). The basis for the map of peak amplitude is 103 seismic reflection lines, each $50 \mathrm{~m}$ apart. Lines were interpolated between each other, yielding a 25 -m spacing before 3-D post-stack migration. These 205 lines with 15-m common reflection midpoints (CMPs) were then interpreted, and the amplitudes extracted. A 20-m median smoothing filter was applied to the map.

seismic reflection expression of the décollement relates to the physical properties of the fault is fundamental to the use of the seismic data for regional studies. In many respects the seismic data reveal the spatial variations of the décollement previously suspected but never actually observed. Many deductions have been made concerning the significance of the map, drawing on the general understanding of how young fault systems develop, on the specifics of the Barbados region, and on the results of previous drilling, which showed that the décollement is a 30- to 50-m-thick layer of clay-rich sediments with scaly fabric and stratal disruptions (J.C. Moore et al., 1982, 1988). These previous drilling data revealed a close association of the décollement with decreasing smectite downhole. We present here a summary of the latest drilling efforts that elucidate fault properties and the origin of the seismic reflection response, which is important for quantitative use of the seismic signature as a regional mapping tool (Figs. 3, 4).

\section{BARBADOS SEISMIC DATA}

The primary improvements afforded by the 3-D data set off Barbados is two-fold: it more properly images the décollement, reducing out-of-plane effects that could cause waveform modifications simply because of improperly placed energy, and it provides a method to map the décollement (and fault physical properties) over a large contiguous area. The 3-D seismic volume, after processing, consisted of 205 lines, each $25 \mathrm{~km}$ long and $25 \mathrm{~m}$ apart (see captions to figures). The original data were collected in June 1992, and the first 3-D migrations, completed a year later, were the basis for refining the ODP Leg 156 drilling program. Since the drilling, estimates of seismic velocities have been improved using post-stack 3-D trial velocity panels along with the two vertical seismic profile (VSP) experiments conducted during Leg 156 . The velocity improvements were combined with a better migration algorithm to improve images of intraprism structures (Moore et al., Chapter 20, this volume; A. Teagan et al., unpubl. data).

The most common waveform associated with the décollement is a compound reflection created from a layer, usually 12-14 m thick based on general seismic modeling (Shipley et al., 1994). This layer has lower impedance (velocity $\times$ density) than the sections above or below. The intervening negative lobe of the waveform's amplitude and position were digitized (latitude, longitude, and depth) for mapping purposes. It was also discovered that the reflection amplitude is a first-order indication of the relative impedance magnitude of the 


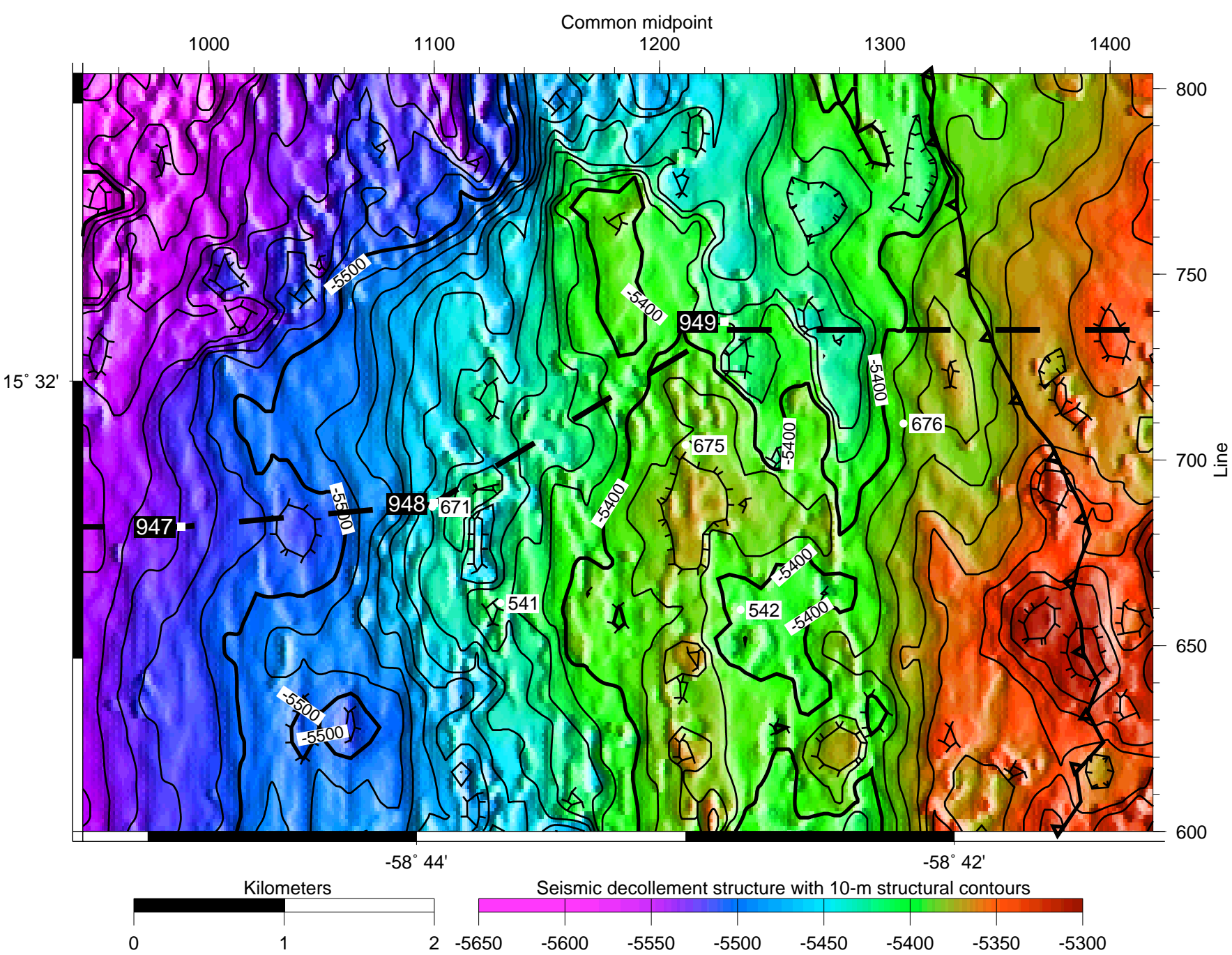

Figure 2. Structural contours of the décollement at a 10-m contour interval. Whereas there are some relations to the amplitude map, no overall pattern emerges. For instance the high-amplitude northeast-trending "channel" does not occupy a structural high, nor do the positive polarity patches occupy lows. These contours were produced by digitizing the 204 seismic lines.

layer because thin-bed tuning modifies the observed amplitudes less than $25 \%$ for a thickness $>5$ m (Shipley et al., 1994; Bangs et al., 1996). We will refer to this waveform as the negative polarity reflection. One-dimensional forward models indicate a maximum velocity decrease of $200 \mathrm{~m} / \mathrm{s}$ in a layer about $12 \mathrm{~m}$ thick (Fig. 5). More typically, the velocity decrease is $80-100 \mathrm{~m} / \mathrm{s}$. These models account for both variations in thickness and interference tuning and assume a Hamilton-type (Hamilton, 1978) velocity-density function. We will express the impedance in terms of velocity, which is a more intuitive unit, assuming the conventional velocity-density relationship of Hamilton (1978). The most important observation is that the seismic response is from a layer with an impedance drop across the top boundary and a step up in impedance at the lower boundary.

Whereas the negative polarity waveform is most characteristic of the décollement, there is a second well-defined waveform referred to as the positive polarity reflection. It is produced by an interface where there is a step up in impedance and a geologic model where the fault is an interface juxtaposing lower velocity-density rocks of the hanging wall with higher velocity-density rocks in the foot-wall, with no (seismically) detectable fault layer. Given perfect conditions, the seismic source used in this experiment should detect the presence of a layer as thin as about $5 \mathrm{~m}$ (Shipley et al., 1994).

A map produced by digitizing the peak amplitude of the décollement seismic reflection on the 205 lines reveals that the negative polarity reflection covers $96 \%$ of the mapped extent of the décollement, even limiting the area to the well-defined décollement west of Site 949. A portion of the map is produced in Figure 1 where a broad band of high negative polarity amplitudes (corresponding to the $>100 \mathrm{~m} / \mathrm{s}$ velocity decrease) trend northeast, not parallel to the trench, ocean plate fabric, or associated with the décollement surface structure, such as closure. An early interpretation suggested the pattern mapped higher porosity and probably higher permeability (Shipley et al., 1994). Could the impedance trend represent a "channel" along which fluid flow is enhanced, or does it just represent a static fluid-filled part of the décollement? Regions of positive polarity reflections, where no layer is detected, comprise only a small portion of the mapped décollement (Fig. 1). These were interpreted as normally compacted sediments that may be stronger patches on the fault surface, having analogies to fault characteristics in the seismogenic zone (Pacheco et al., 1993). A structural map of the reflection décollement 


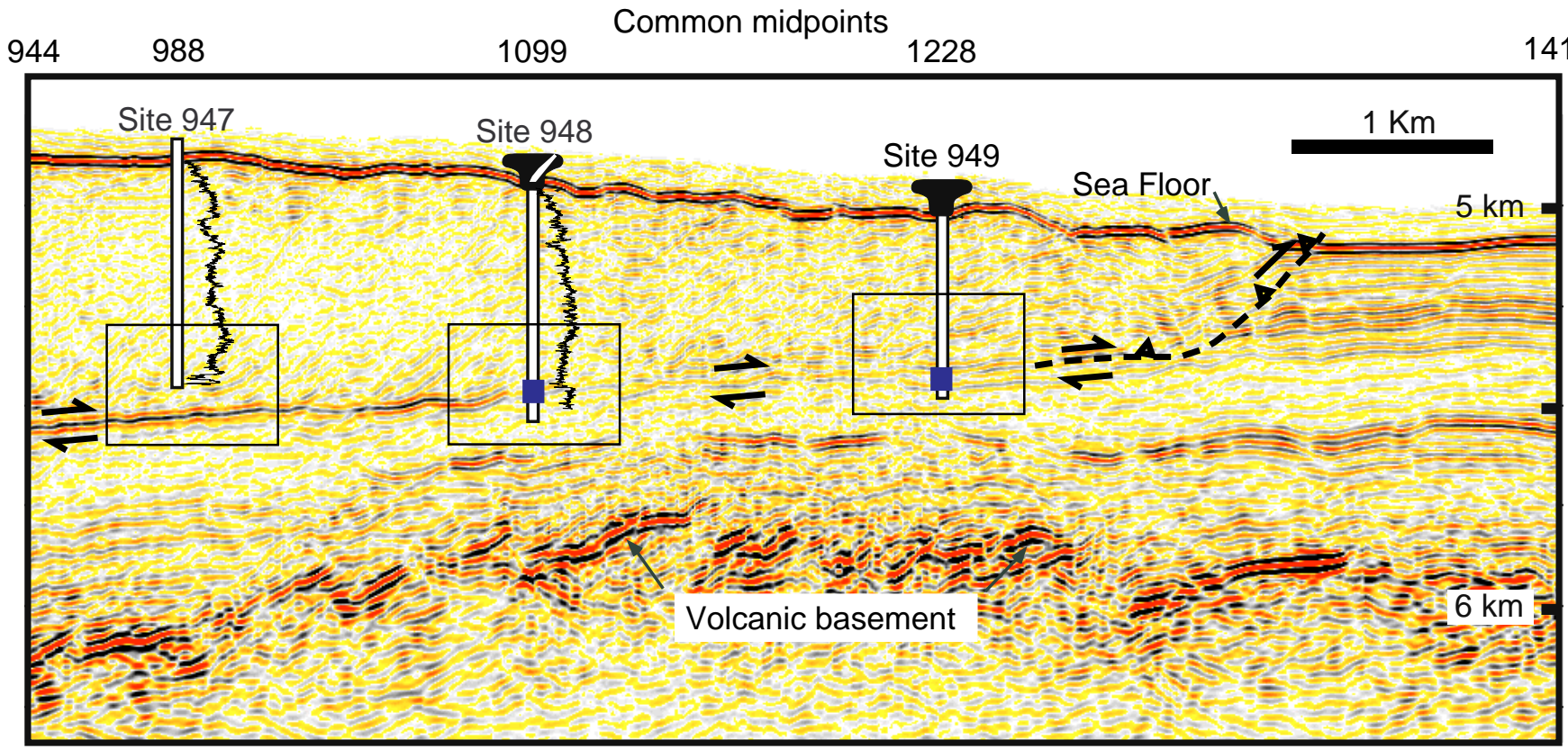

Figure 3. Seismic cross section of three Leg 156 drilling sites. Section was constructed through the three drill sites as shown by the dashed line in Figure 1 . Density logs are illustrated for Sites 947 and 948. Dark blue boxes in décollement represent screened intervals for packer and long-term CORK experiments at Sites 948 and 949 (Zwart et al., Chapter 24, this volume; Becker et al., Chapter 19, this volume; Foucher et al., Chapter 18, this volume). The seismic acquisition and processing steps are detailed elsewhere (Shipley et al., 1994; G.F. Moore et al., 1995). Boxes at the three sites are sections expanded in Figure 4. Orange is high positive amplitude, white is zero amplitude, and gray-to-black is increasing negative amplitude.

shows the general west dip and no simple correlation to the amplitude pattern (Fig. 2). Below we review the properties of the décollement as explored by drilling and then examine the significance of the décollement's various seismic responses.

\section{STRUCTURAL AND SEDIMENTOLOGIC ASPECTS}

In this area of the Barbados Trench, four sites were drilled into the décollement by the Deep Sea Drilling Project (DSDP) and ODP at Sites 948/671, 541, 675, 949, and at two places seaward of the frontal thrust (Sites 543, 672; J.C. Moore et al., 1982, 1988). Defining the top and bottom of the décollement is difficult given the incomplete recovery and disrupted nature of the samples. The best drilling-defined thickness is at Site 948 (the same location as Site 671) where a combination of multiple-cored holes recovered samples with stratal disruptions and scaly fabric that, along with strain-rotation mineral alignment, indicate that the décollement is $40 \mathrm{~m}$ thick (Maltman et al., Chapter 22, this volume; Housen et al., 1996). At other sites, it is estimated to be at least $18 \mathrm{~m}$ thick, although the décollement could be much thicker because there was difficulty in drilling and sampling (Sites 541, 675, and 949). In all cases, it is thicker than the estimated $12 \mathrm{~m}$ thickness of the interval of active dilation. Within the décollement, the deformation is unequally distributed between zones with no discernible deformation and sections with moderate to intense shear fabrics. Thus, the décollement contains locally intense deformation and intervening (mostly undeformed) sections that are centimeters to meters thick. The deformation pattern may be a series of anastomosing shear-bands at all scales (Labaume et al., Chapter 4, this volume).

High clay mineral content is characteristic of the stratigraphic section associated with the décollement (70\%-90\% at Site 948, Meyer and Fisher, Chapter 27, this volume). At Sites 948/671 and 541 there is a distinct shift downsection in the clay minerals from smectite rich (decreasing from about $60 \%$ to $20 \%$ ) to illite rich within the faulted section (Fig. 6). Underwood and Deng (Chapter 1, this volume) suggest that the transition in clay type results in a shear-strength discon- tinuity that causes localization of the décollement near the lithologic boundary.

\section{PHYSICAL PROPERTIES}

Seismic response is primarily controlled by density and velocity. Other factors are also important, but are probably secondary for this data set (e.g., Fresnel zones, noise, rigidity, and attenuation). Site 948/671 is well characterized from a combination of sampling, logging, and vertical seismic profiling, all relevant at the scale of the seismic waveform (Fig. 6). There are two rich data sets of velocity for Site 948 (Fig. 6). One is a series of measurements made on board the ship on cut cubes. These measurements were made about once per meter through the fault zone, characterizing a velocity decrease down-core of about $75 \mathrm{~m} / \mathrm{s}$ measured along the core axis (Brückmann et al., Chapter 8, this volume). The effects of open cracks in cut-cube samples and sediment decompression should make these velocities lower than expected for in situ conditions. The second set of velocity data is a wireline sonic log, although the quality was compromised by hole size and sticky clay, which caused caliper problems within the décollement. Within the 40-m-thick fault zone, the wireline log data indicate a $50 \mathrm{~m} / \mathrm{s}$ increase within the lower part of the décollement, whereas the overall profile, above and below the décollement, suggests nearly constant velocity. The wireline measurement of velocity, although relatively low quality, is more representative of in situ conditions than the discrete-sample laboratory measurements and indicates little velocity effect associated with the décollement zone or its hanging or foot walls.

The wireline density log, which is very susceptible to poor hole conditions, yielded unreliable data. However, the logging-while-drilling (LWD) density profile shows an increase in density of $0.1 \mathrm{~g} / \mathrm{cm}^{3}$ through the 40-m-thick décollement, which was confirmed with laboratory measurements (Fig. 6). The logs reveal 1- and 3-m-thick layers of extremely low density $\left(1.5-1.65 \mathrm{~g} / \mathrm{cm}^{3}\right)$, which are interpreted as open hydrofractures maintained at lithostatic pressure within the 
(A)
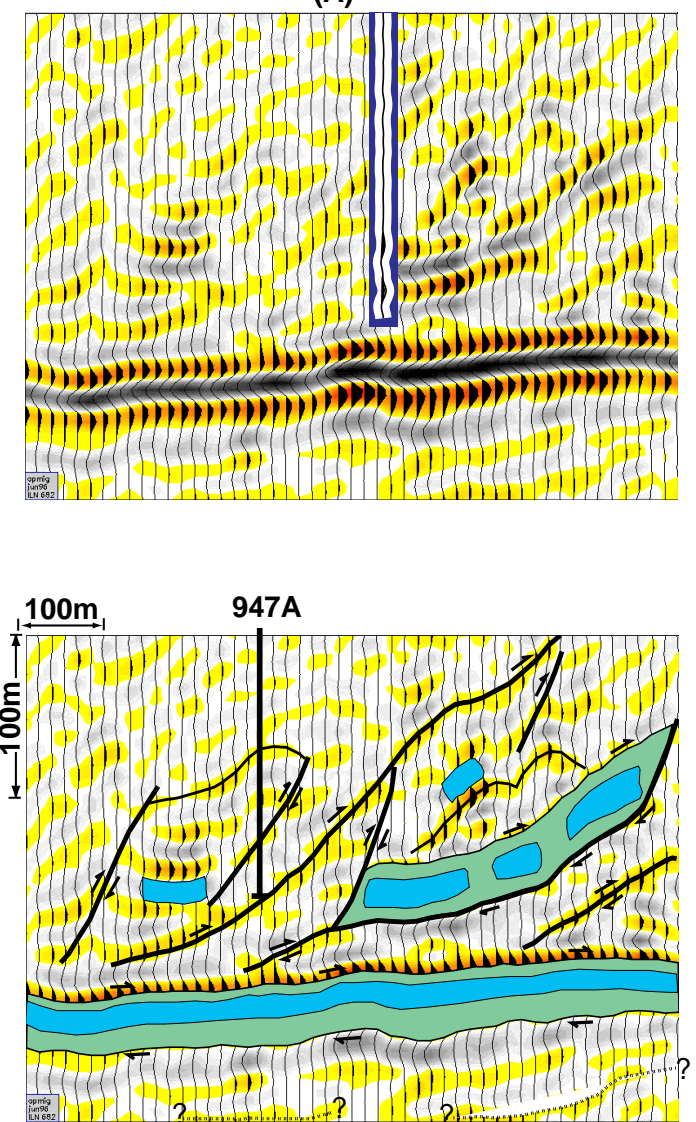

(B)
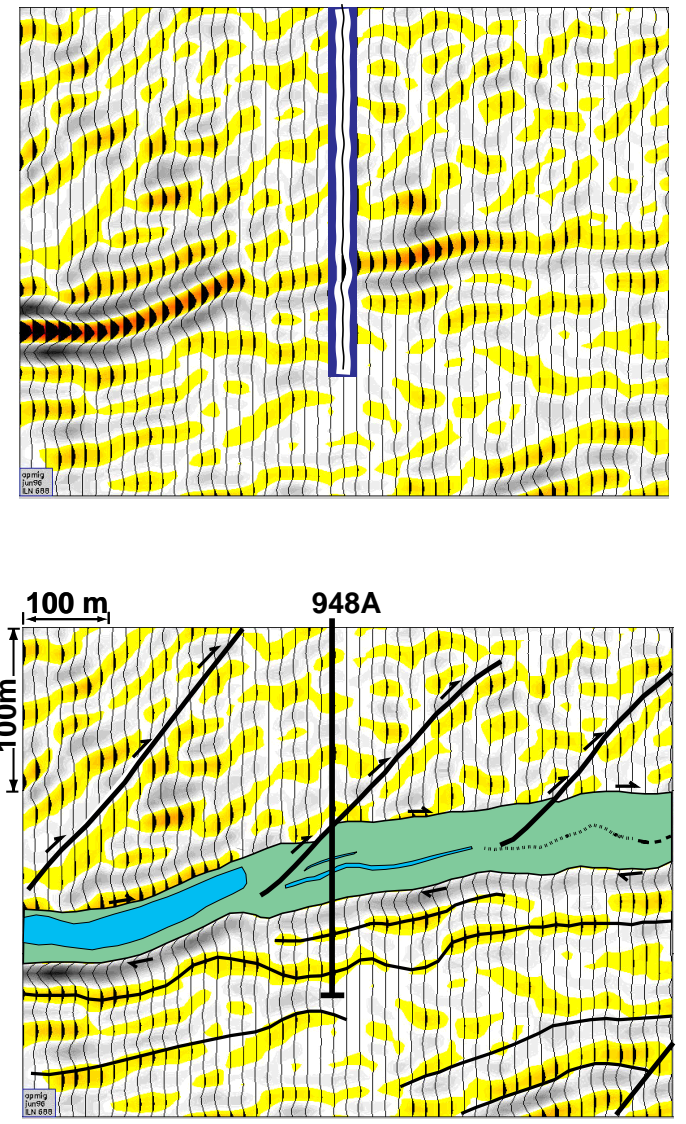

(C)

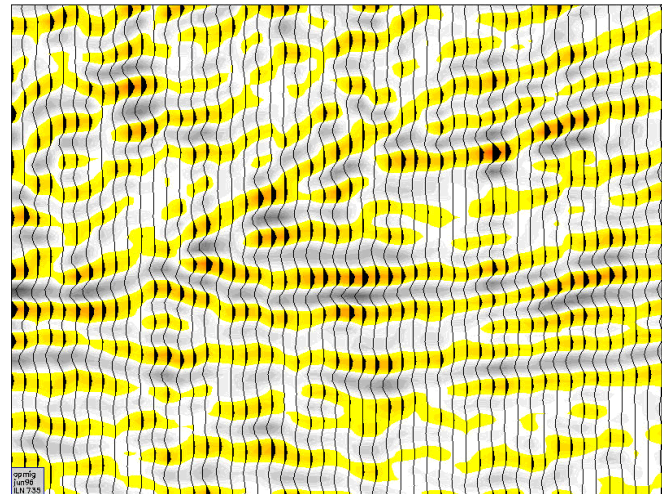

$100 \mathrm{~m}$

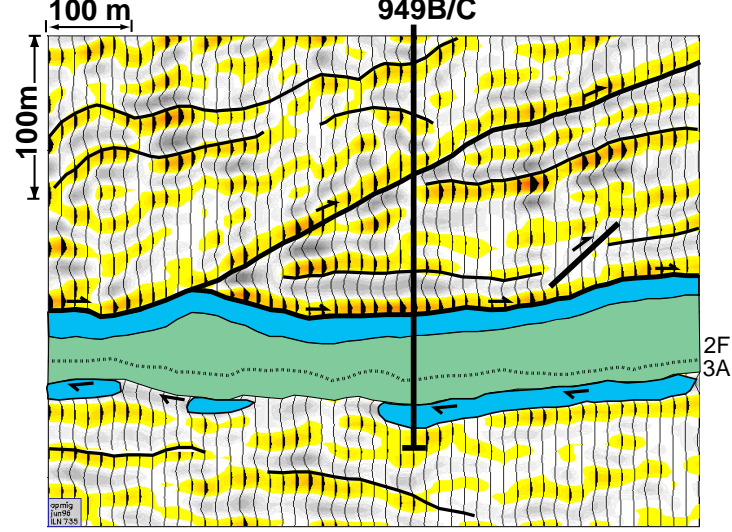

Faults $\quad$ Stratigraphic boundaries

Fluid charged parts of fault zones

Zone of stratal disruptions and scaly fabric $\begin{array}{ll}.25 . \cdots & \text { Stratigraphic boundary with } \\ 3 A & \text { decreasing smectite in unit } 3 \mathrm{~A}\end{array}$

Figure 4. Extreme close-up of Sites 947, 948, and 949 seismic data. The top three are uninterpreted panels with inset synthetic seismograms based on the LWD density logs (as in Fig. 7 ) at Sites 947 and 948. Their location is shown as boxes in Figure 3. The location and depth of Site 947 are shown correctly in the bottom panel. In the top panel of Site 947 (A), the well has been shifted $175 \mathrm{~m}$ east and $20 \mathrm{~m}$ deeper to better match the seismic data (see text). These data illustrate the scale difficulty in interpreting fault properties directly from the seismic data. Blue regions represent interpretation of fluid-rich sections based on the seismic response, modeling, and density logs. The green regions are the extent of the structurally disrupted décollement, interpreted mainly from the drilling at Site 948 (B). The extent of the sedimentologic Unit 2/3 boundary as defined at Site 948 , is correlated eastward to Site 949 (C). Westward, this boundary may occur about $50 \mathrm{~m}$ deeper within the underthrust section (Fig. 3). 


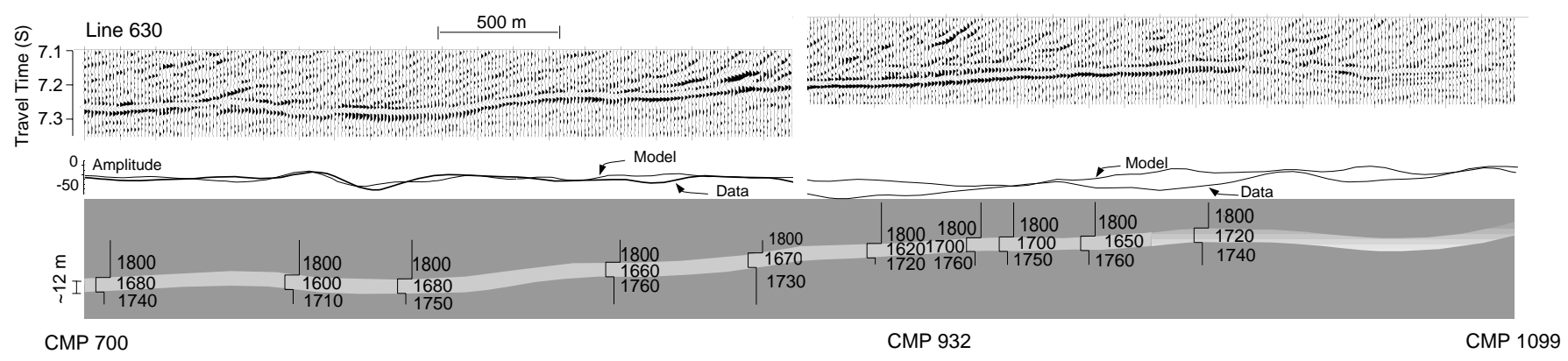

Figure 5. Close-up of a portion of seismic Line 630 (top), which illustrates the variation in décollement waveforms. Bottom is the input to a synthetic model of the section from Bangs et al. (1996). Middle is the difference between the model-produced amplitudes and those observed, which is one measure of the modeling quality. These models illustrate the extreme decrease in velocity of 80-200 m/s needed to account for the waveforms. The purple regions in the map of Figure 1 represent velocity drops of $>100-150 \mathrm{~m} / \mathrm{s}$, although most of the mapped region represents drops of about $100 \mathrm{~m} / \mathrm{s}$ (green). The map in Figure 1 extends from common midpoint (CMP) 944 to 1419, whereas the modeled data extend from CMP 700 to 1099 . These models assumed a $1800 \mathrm{~m} / \mathrm{s}$ velocity for the section immediately above the décollement and generated the best single-layer model to mimic the amplitude and shape of the waveform. Models assume that velocity and density vary in a matter similar to normally compacting sediments. Figure is modified from Bangs et al. (1996).

décollement (J.C. Moore et al., 1995b). The resistivity data confirm that the data are reliable. Packer and long-term pressure measurements verify the presence of super-hydrostatic pressures here (Zwart et al., Chapter 24, this volume; Becker et al., Chapter 19, this volume). These thin layers are well below the resolution of the seismic source waveform used in the seismic reflection survey and do not contribute to the recorded seismic response (Fig. 6). On a large scale, the density increase is a result of the lithologic transition and decreasing water-layer-rich smectite down core. Brückmann et al. (Chapter 8 , this volume) confirms that the porosity calculated from the density is nearly constant through the décollement after adjusting for the bound water that is associated with changing clay mineralogy (Brown and Ransom, 1996). Whereas the porosity doesn't change much, the density is the driving force for the seismic signal here. A synthetic seismogram created by convolving a wavelet with an impedance function derived from the density and the linear increasing velocity created a response very similar to the waveform from the seismic survey (Fig. 6; Moore et al., Chapter 20, this volume). The presence of the lithologic change in clay mineralogy is the cause of the impedance increase and the resulting positive polarity waveform (Moore et al., Chapter 20, this volume; Tobin and Moore, Chapter 9, this volume).

Site 947 provides other relevant information regarding acoustic properties of the décollement. Here density logging stopped about 78 $\mathrm{m}$ above the seismic expression of the décollement (Fig. 7). The density log showed a complicated profile in the bottom $50 \mathrm{~m}$ of the hole (Fig. 8). The density decreases from 0.3 to $0.4 \mathrm{~g} / \mathrm{cm}^{3}$ over a $14-\mathrm{m}-$ thick interval. The only way to explain densities of $1.50-1.65 \mathrm{~g} / \mathrm{cm}^{3}$ at $540 \mathrm{mbsf}$ is by fluids and fluidized sediments within hydrofractures (J.C. Moore et al., 1995b). The thick, low-density section is easily detectable seismically (see Figs. 4A, 8C), and, thus, we probably logged a fault splay above the décollement (see Discussion section, this chapter). The log is the best analogue we have to the commonly occurring negative polarity reflection.

Unique data from the Oregon frontal thrust area has been used to estimate velocity changes associated with effective pressure to evaluate the cause of the fault reflectivity observed there (Tobin et al., 1994). In a similar study of five samples from the Barbados Trench above and below the décollement, the general result is one of only modest velocity change as the samples were cycled from in situ to near-lithostatic fluid pressures (Tobin and Moore, Chapter 9, this volume). The maximum observed change in velocity was of the order of about $100 \mathrm{~m} / \mathrm{s}$, with velocities at in situ conditions equivalent to the wireline sonic results. The velocity change associated with the blue area on the map in Figure 1 is predicted to be about $100-150 \mathrm{~m} / \mathrm{s}$ lower by modeling (Fig. 5; Bangs et al., 1996). However, Bangs et al.
(1996) used a Hamilton-type velocity-density function that predicts a $0.2 \mathrm{~g} / \mathrm{cm}^{3}$ density decrease associated with the velocity change. Tobin and Moore (Chapter 9, this volume) found that the density decrease is much smaller; their $100 \mathrm{~m} / \mathrm{s}$ velocity decrease is associated with a density decrease of only about $0.1 \mathrm{~g} / \mathrm{cm}^{3}$. Thus, this new data require the results of Bangs et al. (1996) to be modified to an even greater negative impedance contrast. Tobin and Moore (Chapter 9, this volume) conclude that to achieve and maintain low densities, the décollement must be hydrofractured at lithostatic pressure.

\section{DISCUSSION}

Calibration of the differing seismic responses of the décollement was an original objective of the Leg 156 project. Operational difficulties at Site 948 did not allow sufficient time to return to complete Site 947, so we did not obtain a direct calibration of the high-amplitude negative polarity reflection. We did a much better characterization at Site 948 , the site of the characteristic normal polarity reflection.

\section{Site 947 as a Non-décollement Hydrofractured Reference Site}

At the base of Site 947, the density log is probably representative of a hydrofractured layer, and if we correlate this to the seismic reflection data, it provides a method to calibrate the negative polarity waveform. The logged density revealed a large excursion to as low as $1.5 \mathrm{~g} / \mathrm{cm}^{3}$ in a $14-\mathrm{m}$-thick zone at $540-554 \mathrm{mbsf}$ with the data quality confirmed by the resistivity log run (Fig. 8). This layer is of sufficient thickness and impedance to produce a reflection, if it has sufficient lateral extent. At the projected position of Site 947, the low density does not correlate with any recorded seismic reflection (Fig. 4A, bottom). The computed location of the hole relative to the seismic data has several potential uncertainties. One issue is that the seismic data is located with differential global positioning system (GPS) navigation, whereas the JOIDES Resolution is located with conventional dithered GPS. Also, the location of the drill bit, relative to the ship, is uncertain. Altogether, the uncertainties could result in as much as a 200-300 m error in relative position. Because we had no VSP at this site, the velocity-depth function is not known extremely well, but probably is not in error by more than $25 \mathrm{~m}$, and thus, there is little likelihood that we actually reached the décollement (A. Teagan, unpubl. data). Our best estimate for the depth to the décollement is from the unpublished velocity study of Teagan, which estimates the velocity at $1836 \mathrm{~m} / \mathrm{s}$, traveltime at $701 \mathrm{~ms}$, and, thus, the depth at $644 \mathrm{mbsf}$. 
A

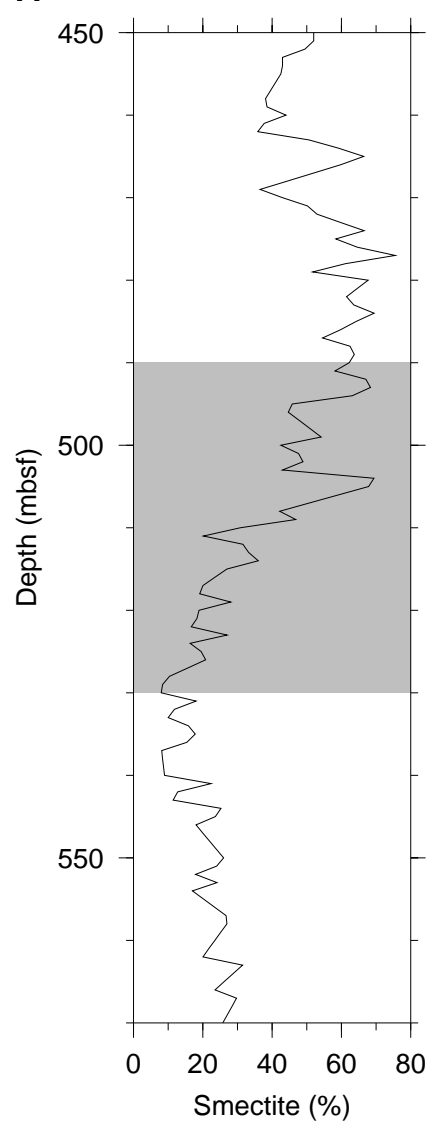

B

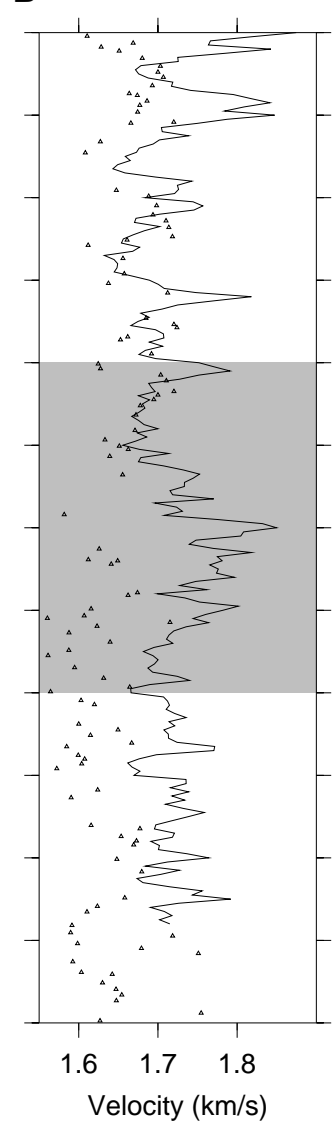

C

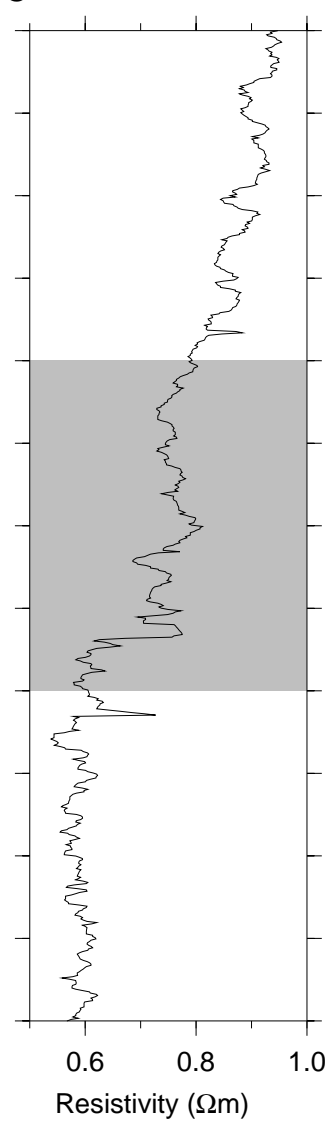

D

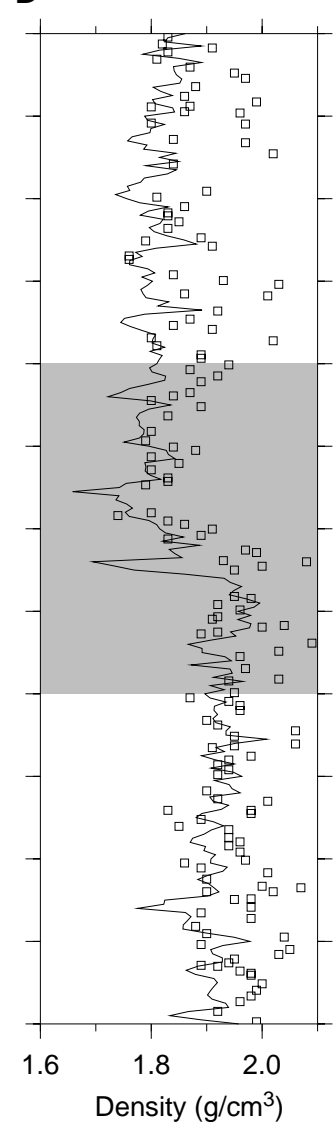

E

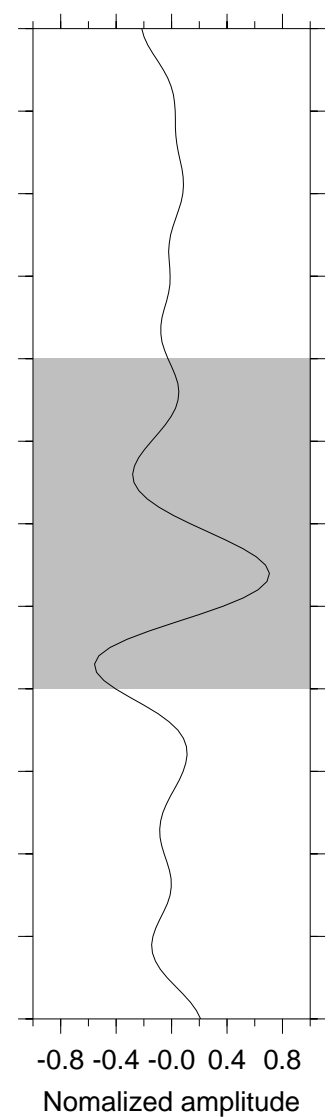

Figure 6. Site 948 downhole profiles through the structurally defined décollement from 490 to $530 \mathrm{mbsf}$ (shaded region). A. The relative percentage of clay minerals in the $<1-\mu \mathrm{m}$ size fraction (Underwood and Deng, Chapter 1, this volume). B. Wireline sonic logs resampled at a $0.5-\mathrm{m}$ interval. Triangles are velocity measurements on laboratory samples, both along core axis and transverse (Brückmann et al., Chapter 8, this volume). C. LWD resistivity data resampled at a 0.5-m interval. D. Density LWD profile resampled at a 0.5-m interval. Squares are laboratory measured index properties. E. Synthetic seismogram created by using the density log, linear velocity function, and source wavelet derived from the field data (Moore et al., Chapter 20, this volume).

We postulate that Site 947 penetrated the acoustic anomaly $200 \mathrm{~m}$ either to the east or west of the illustrated drill site (see relocation in Fig. 4A, top). These anomalies have the same waveform characteristics as the negative polarity reflection associated with the décollement. The anomalies located about $100 \mathrm{~m}$ above the décollement might be fault splays or flats on fault splays, preserved sedimentary bedding, or even relict portions of the décollement. If it had been possible to complete the reprocessing of the data (with the improved velocity functions and migration algorithm) before the drilling program, we would have searched for a drill site away from these shallower anomalies. We interpret the fault zone to be at lithostatic pressures with enhanced fluid content responsible for the low density. Because this fault has characteristics very similar to the décollement seismic waveform, we believe that much of the décollement is a 10 - to $14-\mathrm{m}$-thick, $1.5-1.65 \mathrm{~g} / \mathrm{cm}^{3}$ section that was almost certainly created by hydrofracturing and enhanced fluid content. This confirms modeling estimates of thickness and impedance of the negative polarity reflection.

\section{Site 948 as a Low Fluid Content Reference Site}

The décollement is well sampled at Site 948, but how representative is the lithology, physical properties and fluids for elsewhere? At this site the fault-plane reflection signature is not of a layer but of an interface downward to higher impedance. Because so much of our core-log data is associated with Site 948, there is a significant possibility of bias in using this site as the general analogue for the geologic setting. How pervasive is the lithologic pattern and decreasing smectite through the décollement? The position of Site 948 is over a northeast-trending 2- to 3-km-wide, 150-m-high basement horst (Fig. 3). Much of the relief is attenuated by preferential sediment infilling before deposition of the smectite-rich clays. However, the décollement appears to be about $50 \mathrm{~m}$ lower in the section at Site 948 compared to areas located over basement lows (e.g., Site 947; Fig. 3). The reflecting horizons, within the underthrust section, terminate against the décollement near Site 948. This is not surprising since low-angle thrusts do not precisely follow lithologic boundaries. This leaves the possibility that the physical properties of the foot-wall vary within the mapped area as the fault juxtaposes smectite-poor and smectite-rich sections in some areas (Site 948), but may be fully within the smectite-poor section in other areas. However, the smectite-poor lithologies have never been sampled above the active décollement in any of the DSDP or ODP coring sites; thus, the lithologic section in the footwall probably does not vary substantially, or this situation is rare. Detailed mapping of the stratigraphic relationships are in progress $(\mathrm{Z}$. Zhao et al., unpubl. data). We believe that the foot-wall is likely to be less variable than the décollement hanging wall where faults splaying from the décollement modify the overlying section at many different scales.

Site 948 was situated to calibrate the seismic signal associated with the normal polarity décollement (Fig. 3). Using the density log, the generated synthetic seismogram matches the survey data. The density increase of about $0.1 \mathrm{~g} / \mathrm{cm}^{3}$, a result of the downhole decrease in smectite and the reduction of interlayer water, is consistent. The 


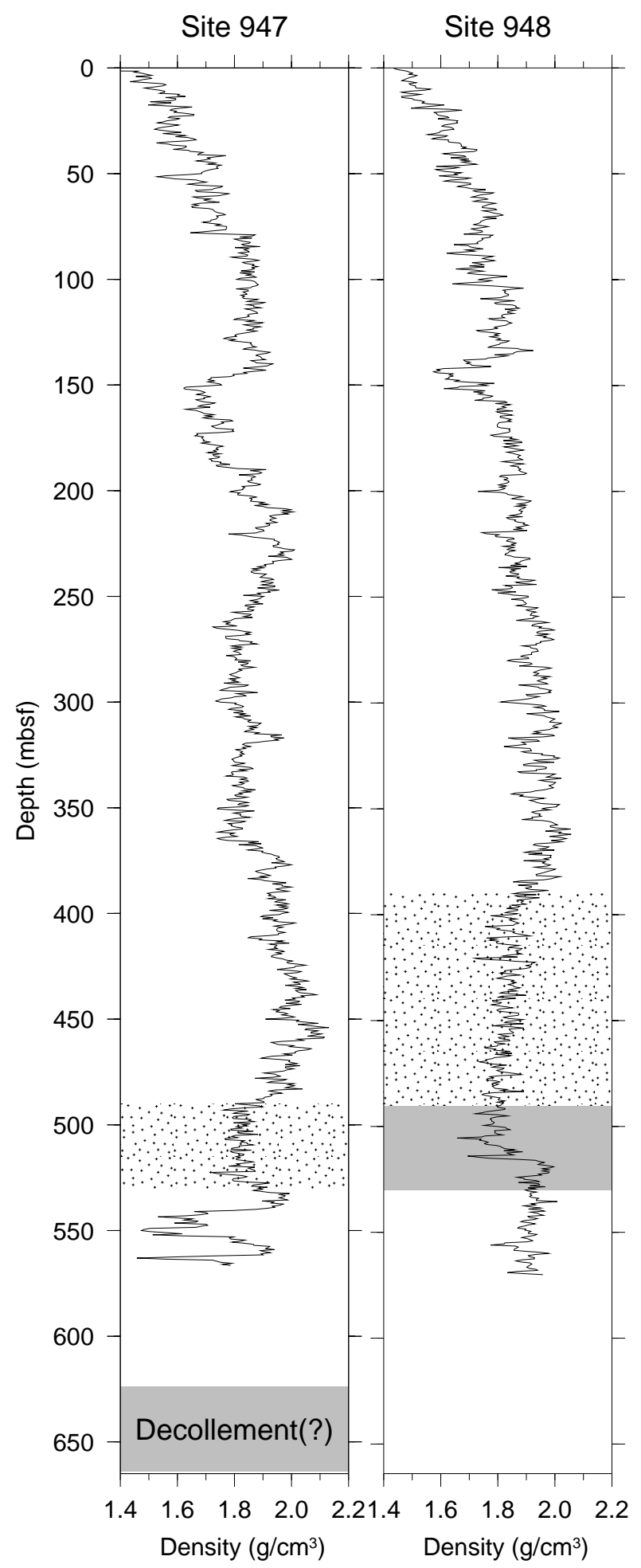

Figure 7. Density logs for Sites 947 and 948 from the LWD tools. The stippled areas highlight the regions of density lows in the accretionary prism just above the fault splay (at Site 947) and the décollement (at Site 948). These sections have been attributed to elevated fluid pressures. This trend may be characteristic of the décollement hanging wall. Shaded portion of Site 948 is the structurally defined décollement. observed meters-thick low-density spikes are not detectable with the source wavelet used in the experiment (Moore et al., Chapter 20, this volume). Just to the west, the seismic signature begins to develop into the more characteristic low-impedance-layer negative polarity reflection (although it is complicated in Figure 4B by interference from a nearby overlying sedimentary horizon). It appears that the boundary between the two types of waveforms is broadly transitional, but as interpreted in Figure 4B, some places may be controlled by a fault splay off the décollement that isolates fluid-charged regions of the décollement and fluid migration westward. At this location, the geochemical evidence for fluid flow is at the top of the décollement, at $490 \mathrm{mbsf}$ (Kastner et al., Chapter 25, this volume).

How representative is Site 948 of the overlying accretionary prism? The best data comes from the logging because of its more continuous nature and presumably near in situ measurements. Density inversions at Site 947 above the fault splay at 490-530 mbsf and at Site 948 above the décollement from 390 to 500 mbsf (stippled regions of Figure 7) are interpreted as regions of moderately abnormal fluid pressures (J.C. Moore et al., 1995b; Tobin and Moore, Chapter 9 , this volume). The density logs at both sites are shifted lower $0.1-$ $0.2 \mathrm{~g} / \mathrm{cm}^{3}$ from the projected downhole trend. In addition, the VSP data at Site 949 also suggest this inversion, so the density inversion at the base of the accretionary prism may be a widespread anomaly. However, the overall effect is probably minor, as at Site 948 . Here the depressed densities associated with the broad fluid-pressure anomaly within the prism increase the positive impedance contrast, helping increase the amplitude of the positive reflector to detectable signal levels. Even so, the positive impedance associated with the decreasing smectite downhole should occur as a primarily inherited stratigraphic reflection in the area, because the smectite-rich section is found in all holes that have reached the décollement (Underwood and Deng, Chapter 1, this volume). Although the general fluid-pressure driven low densities might increase the positive amplitude, the negative amplitudes should be depressed. However, in detail at Site 947, the low density portion of the fault splay is surrounded by $\sim 5-\mathrm{m}$-thick section of higher densities $\left(1.9 \mathrm{~g} / \mathrm{cm}^{3} ;\right.$ Fig. 8 , stippled region). These higher densities within the fault zone may be caused by shearing-induced tectonic overconsolidation, although in this case, the actual density is still depressed below the overall downhole trend (Fig. 7). As an analogue, this suggests that as the décollement undergoes more total shear (to the west), it is more likely to have higher densities, thus increasing the apparent impedance drop into a hydrofractured layer.

\section{Site 949 as an Incipient Décollement Site}

Site 949 is situated in a more structurally and stratigraphically complicated region very close to the deformation front. This site was chosen as an alternate to Site 947 when the time remaining was insufficient for drilling and sampling of Site 947 . Traced to the southeast, the lower of two negative polarity reflections correlates to the décollement at Site 948, although here the upper reflection is clearly traced as a thrust to the seafloor (see Fig. 3). VSP data were critical for determining the position of the reflecting horizons to depth in the hole. The sedimentologic units are correlated from Site 948 and were also identified in the fragmentary stratigraphic section constructed from rare core samples at Site 949. Until continuous logging is completed, Site 949 does not contribute to the waveform calibration.

\section{CONCLUSIONS}

Near the décollement, we conclude that the natural lithologic density variations are about $0.1 \mathrm{~g} / \mathrm{cm}^{3}$ with associated small velocity changes insufficient to account for the décollement reflection characteristics, except for the positive polarity reflection at Site 948 . A reduction in density of $0.3 \mathrm{~g} / \mathrm{cm}^{3}$ that was observed in the $12-\mathrm{m}$-thick 
A

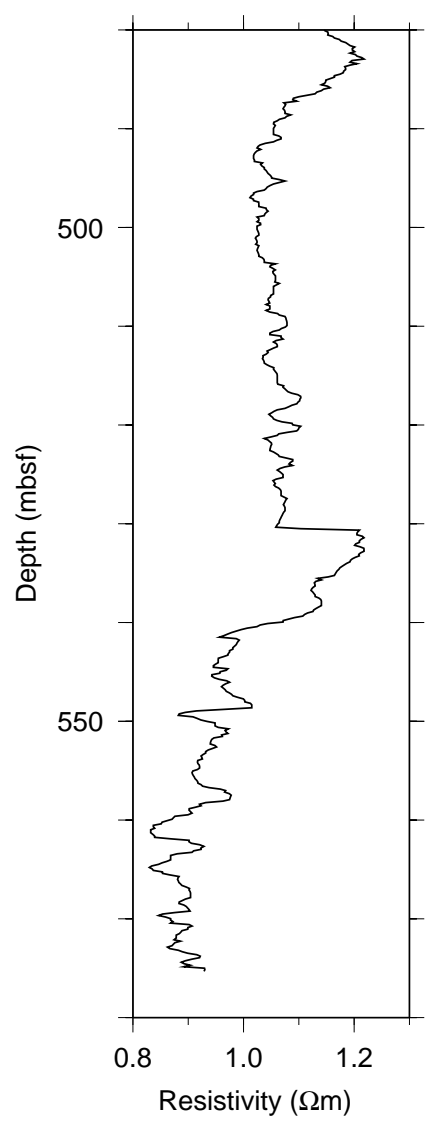

B

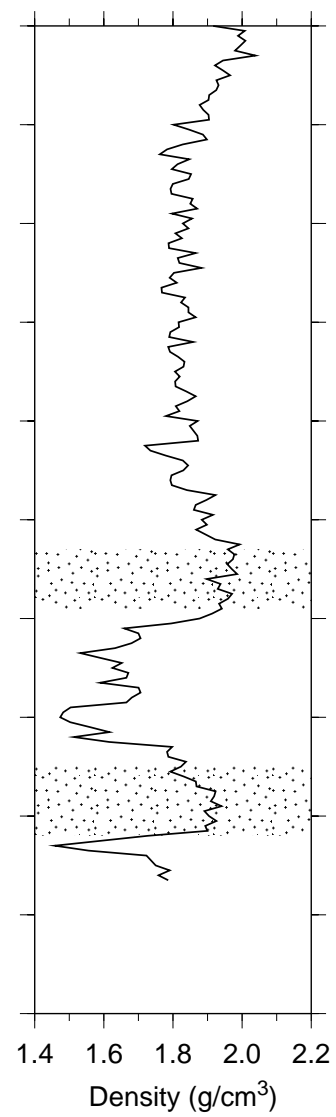

C

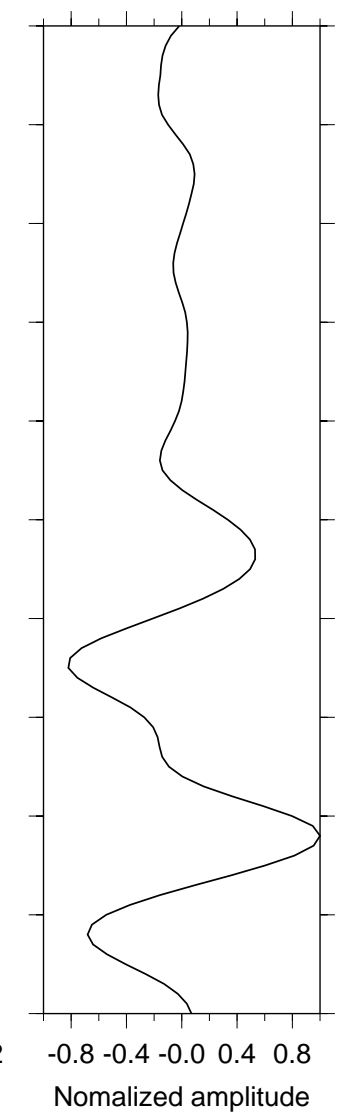

Figure 8. Portion of (A) LWD resistivity $\log$ and $(\mathbf{B})$ density $\log$ at Site 947 , both resampled at a $0.5-\mathrm{m}$ interval. Stippled zones might be shearing-induced density increases in the fault zone surrounding the $\sim 12$-m-thick, $1.6 \mathrm{~g} / \mathrm{cm}^{3}$ hydrofractured section. However, these densities are depressed relative to normally expected downhole increases from compaction, so shear-induced strain is not necessarily the only explanation for the density profile. C. A synthetic seismogram created using the density log (Moore et al., Chapter 20, this volume). regions may be more disconnected or divided into more compartments than it appears. This may be one of the explanations for the Site 948 positive polarity patch where limited mapping suggests a possible relationship to high-angle faults that intersect or splay from the décollement and isolate a compartment (Fig. 4B).

Significantly higher resolution seismic data is needed to attempt to define the detailed stratigraphy and deformation near the décollement and a few more carefully placed drill sites will eventually be required to fully calibrate the seismic response so the waveforms can be inverted directly for porosity, permeability, and perhaps fluid pressure. As a first step, further calibration of the seismic waveform should occur in late 1996 when the JOIDES Resolution returns to the area for additional logging.

\section{ACKNOWLEDGMENTS}

This work was supported by JOIDES member countries for operating the Ocean Drilling Program. The seismic reflection survey was supported by NSF Grants OCE-9119336 (UH), OCE-9116350 (UCSC), and OCE-9116172 (UT). Additional support was provided by USSAC for post-cruise interpretation. We also acknowledge two anonymous reviewers.

\section{REFERENCES}

Bangs, N.L.B., and Westbrook, G.K., 1991. Seismic modeling of the décollement zone at the base of the Barbados Ridge accretionary complex. $J$. Geophys. Res., 96:3853-3866.

Bangs, N.L., Shipley, T.H., and Moore, G.F., 1996. Elevated fluid pressure and fault zone dilation inferred from seismic models of the northern Barbados Ridge décollement. J.Geophys. Res., 101:627-642. 
Brown, K.M., and Ransom, B., 1996. Porosity corrections for smectite-rich sediments: impact on studies of compaction, fluid generation, and tectonic history. Geology, 24: 843-846.

Carson, B., Suess, E., and Strasser, J.C., 1990. Fluid flow and mass flux determinations at vent sites on the Cascadia margin accretionary prism. $J$. Geophys. Res., 95:8891-8897.

Fisher, A.T., Zwart, G.T., and ODP Leg 156 Scientific Party (T.H. Shipley co-chief scientist), 1996. Relation between permeability and effective stress along a plate-boundary fault, Barbados accretionary complex. Geology, 24:307-310.

Hamilton, E.L., 1978. Sound velocity-density relations in sea-floor sediments and rocks. J. Acoust. Soc. Am., 63:366-377.

Housen, B.A., Tobin, H.J., Labaume, P., Leitch, E.C., Maltman, A.J., and ODP Leg 156 Shipboard Science Party, 1996. Strain decoupling across the décollement of the Barbados accretionary prism. Geology, 24:127130

Kastner, M., Elderfield, J., and Martin, J.B., 1991. Fluids in convergent margins: what do we know about their composition, origin, role in diagenesis and importance for oceanic chemical fluxes. Philos. Trans. R. Soc. London A, 335:243-259.

Kulm, L.D., et al., 1986. Oregon subduction zone: venting, fauna, and carbonates. Science, 231:561-566.

Moore, G.F., and Shipley, T.H., 1993. Character of the décollement in the Leg 131 area, Nankai Trough. In Hill, I.A., Taira, A., Firth, J.V., et al., Proc. ODP, Sci. Results, 131: College Station, TX (Ocean Drilling Program), 73-82.

Moore, G.F., Shipley, T.H., Stoffa, P.L., Karig, D.E., Taira, A., Kuramoto, S., Tokuyama, H., and Suyehiro, K., 1990. Structure of the Nankai Trough accretionary zone from multichannel seismic reflection data. J. Geophys. Res., 95:8753-8765.

Moore, G.F., Zhao, Z., Shipley, T.H., Bangs, N., and Moore, J.C., 1995. Structural setting of the Leg 156 area, northern Barbados Ridge accretionary prism. In Shipley, T.H., Ogawa, Y., Blum, P., et al. (Eds.), Proc. ODP, Init. Repts., 156: College Station, TX (Ocean Drilling Program), 13-27.

Moore, J.C., Biju-Duval, B., Bergen, J.A., Blackington, G., Claypool, G.E., Cowan, D.S., Duennebier, F., Guerra, R.T., Hemleben, C.H.J., Hussong, D., Marlow, M.S., Natland, J.H., Pudsey, C.J., Renz, G.W., Tardy, M., Willis, M.E., Wilson, D., and Wright, A.A., 1982. Offscraping and underthrusting of sediment at the deformation front of the Barbados Ridge: Deep Sea Drilling Project Leg 78A. Geol. Soc. Am. Bull., 93:1065-1077.

Moore, J.C., Mascle, A., Taylor, E., Andreieff, P., Alvarez, F., Barnes, R., Beck, C., Behrmann, J., Blanc, G., Brown, K., Clark, M., Dolan, J.F., Fisher, A., Gieskes, J., Hounslow, M., McLellan, P., Moran, K., Ogawa, Y., Sakai, T., Schoonmaker, J., Vrolijk, P., Wilkens, R.H., and Williams, C., 1988. Tectonics and hydrogeology of the northern Barbados Ridge: results from Ocean Drilling Program Leg 110. Geol. Soc. Am. Bull., 100:1578-1593.

Moore, J.C., Moore, G.F., Cochrane, G.R., and Tobin, H.J., 1995a. Negativepolarity seismic reflections along faults of the Oregon accretionary prism: indicators of overpressuring. J. Geophys. Res., 100:12,895$12,906$.

Moore, J.C., Shipley, T.H., Goldberg, D., Ogawa, Y., and Leg 156 Shipboard Scientific Party, 1995b. Abnormal fluid pressures and fault-zone dilation in the Barbados accretionary prism: evidence from logging while drilling. Geology, 23:605-608.

Moore, J.C., and Vrolijk, P., 1992. Fluids in accretionary prisms. Rev. Geophys., 30:113-135.

Pacheco, J.F., Sykes, L.R., and Scholz, C.H., 1993. Nature of seismic coupling along simple plate boundaries of the subduction type. J. Geophys. Res., 98:14,133-14,159.

Shipley, T.H., and Moore, G.F., 1986. Sediment accretion, subduction, and dewatering at the base of the trench slope off Costa Rica: a seismic reflection view of the décollement. J. Geophys. Res., 91:2019-2028.

Shipley, T.H., Moore, G.F., Bangs, N.L., Moore, J.C., and Stoffa, P.L., 1994. Seismically inferred dilatancy distribution, northern Barbados Ridge décollement: implications for fluid migration and fault strength. Geology, 22:411-414.

Shipley, T.H., Stoffa, P.L., and Dean, D.F., 1990. Underthrust sediments, fluid migration paths and mud volcanoes associated with the accretionary wedge off Costa Rica: Middle America trench. J. Geophys. Res., 95:8743-8752.

Sibson, R.H., 1981. Fluid flow accompanying faulting: field evidence and models. In Simpson, D.W., and Richards, P.G. (Eds.), Earthquake Prediction: An International Review. Geophys. Monogr., Maurice Ewing Ser., Am. Geophy. Union, 4:593-603.

Tobin, H.J., Moore, J.C., MacKay, M.E., Orange, D.L., and Kulm, L.D., 1993. Fluid flow along a strike-slip fault at the toe of the Oregon accretionary prism: implications for the geometry of frontal accretion. Geol. Soc. Am. Bull., 105:569-582.

Tobin, H.J., Moore, J.C., and Moore, G.F., 1994. Fluid pressure in the frontal thrust of the Oregon accretionary prism: experimental constraints. Geology, 22:979-982.

Westbrook, G.K., and Smith, M.J., 1983. Long décollements and mud volcanoes: evidence from the Barbados Ridge Complex for the role of high pore-fluid pressure in the development of an accretionary complex. Geology, 11:279-283.

Date of initial receipt: 1 August 1996

Date of acceptance: 7 January 1997 Ms 156SR-034 